\title{
Incarnational Theology in Africa: A Christo-Centric Perspective
}

\author{
Nmah, P.E. \\ Department of Religion and Human Relations, Nnamdi Azikiwe University Awka, Nigeria \\ Email: patricknmah@yahoo.com \\ Udezo, B. O. S. \\ Department of Religion and Human Relations, Nnamdi Azikiwe University Awka, Nigeria \\ Email: Bensonudezo@gmail.com
}

\section{Doi:10.5901/mjss.2015.v6n3s2p263}

\begin{abstract}
In the course of this research, I observed two challenges in most of the post-colonial African theological discussions: lack of precision and inadequate methodology. These attempts generally suffer from two weaknesses. First, they rarely go beyond stressing the need for African theology by way of illustration. Secondly, quite often the proponents of such African theologies have gone about their task without a conscious examination of the methodology involved. Generally speaking, this work observed that the varying theological approaches of African theologians have brought the post-colonial African church to cross-roads. This is because African church has been exposed to many options ranging from vain syncretism, universalism, Chris-paganism, humanism, Africanization and so on. The method of approach is descriptive with the review of related extant material.
\end{abstract}

\section{Introduction}

According to Fashole-Luke (1974), African Christian theology involves steeping oneself in the patterns of thought of traditional African religions and studying Christianity in the light of the heritage, thus endeavouring to find points of contact between African traditional beliefs and Christian beliefs so that Christianity can be more effectively and relevantly proclaimed to the African situation. It must produce a theology which bears the distinctive stamp of African thinking and reflection. This African imprint is very important, but it is not enough to constitute an African theology.

African theology seeks to relate biblical revelation to African traditional culture and religion. By African theology we mean a theology which is based on the biblical faith and speaks to the African "soul" or is relevant to African. It is expressed in categories of thought which arise out of the philosophy of the African people.

The driving force for European militant expedition in Africa could be reduced to two words: "wealth and power" Before the 1870s the European states were reluctant to commit themselves deeply to colonial adventures were the political and economic value was not readily apparent (Onyenechehie, 2007). In the case, the Europeans could be grouped into four categories:(1) government officials; (2) traders, teachers and missionaries, sponsored by their home organizations; (3) self-employed traders and farmers, whose pure intention was to acquire wealth in the colony and retire later in the metropolis of Europe; (4) settlers proper, principally farmers, but including those engaged in administration, mining and commerce, who treated their adopted colony as home. One thing which all the categories of Europeans had in common was superiority complex over African people with the political power behind them, they dominated the continent.

The Europeans overvalued their culture and undermined the cultures of the African peoples the identity of the African was damaged. This sense of cultural superiority, led the Europeans into the thinking, for a time, that it was their right to rule other people. African historians observe the rising time of racism during the period under review. For example, "the majority of cultivatable land was alienated to Europeans, and the proportion of Europeans to the indigenous inhabitants could rise as high as 30\% to $40 \%$. Such was the case in East and South Africa.

Educationally, the colonial system in Africa had many contradictions. As Van (nd) observed:

In schools, Africans were taught the principles of equality, fair play and respect for human right. But in real, every day life, it was a different story: The reality conflicted sharply with the textbook, dealism. In place of fair and equal treatment 
based on merit, Africans found themselves discriminated against, in their own countries and labeled enemies of their people when they asked for the right for spiritual, political, economic and cultural self-determination (p.50).

What becomes obvious is that the colonial educational strategy was directed toward exporting to Africa, the art, culture, language, history and geography of Europe. Their textbooks taught us about the battle of the Gauls, about the life of Joan Arc, or about Napoleon, the poems of Larmarine and so on as if Africa never had a history, a past, a geographical existence, and a cultural life. It was also aimed at keeping the Africans from knowing their background and cultural heritage. Above all, colonial educational system did not allow the African to reflect on personal identity. These writings which interact with pre-colonial, and post-colonial Africa, presuppose that Africa's identity was lost to foreign influence in nineteenth century.

The implication here is that the political and religious intrusion of the white man in the $19^{\text {th }}$ century Africa has robbed Africans of their cultural identity. It is with this understanding of recovering the lost image of Africans that African theology is constructed. Doing incarnational theology in Africa, therefore, is a quest for selfhood and must be put in that context to ensure proper understanding and representation.

The key crux of the research is that Christianity being an incarnational religion, should be universally incarnational in its theology to all peoples, but especially to the Africans. The term "incarnational theology in Africa" represents this position. Just as God became flesh in Christ in a historical context so that his creatures might apprehend him completely. Christian theology should become flesh in the cultural worldview of the Africans as well.

Since African culture was already judged as primitive and pagan, the western heralds did not consider giving the African background any hearing. The contention of the African today comes from the awareness that the historical development of Christian doctrinal formulations were shaped by the occurred cultural influences over the years. Africans feel that when Christianity came to Africa, they were deprived of their chance to make theological contributions to a theological process which is supposed to be universal. Instead, theology brought to Africa, was dogmatically closed, and was not alloyed to interact with Africans in their context.

The incarnational theological method, on the other hand, includes that this divine self-disclosure in Jesus Christ is a continuous process which becomes existentially salvafic only when each people perceive and appropriate it in their cultural context. In this respect, therefore, the term "incarnational theology in Africa," simply means a Christian theology presented in the framework of African theology and culture, especially as it affects existential issues in the selfconsciousness of the African.

\section{Conceptual Framework}

Thus, for the gospel message to be meaningful to Africans, it must be incarnated in African culture. For the synthesis between culture and faith is not only a demand of culture, but also of the faith. The term "adaptation" and the approach it designates, has been abandoned as too superficial and inadequate. Similarly, terms such as indigenization, Africanization, "accommodation", and "Christianization" have also been abandoned for not going far enough. They are said to represent processes that do no more than reproduce an African version of Western Christianity. Many African theologians today would rather opt for the term "inculturation" and call for African inculturation theology. Some prefer the term "incarnation".

The theology of "incarnation" on the other hand derives its model from Christology. An African theology which effects the incarnation of Christianity in African cultures will not change the essential contents of the gospel message, but should tune the contents of the message in response to the cultural context of the peoples to whom the message is addressed. It may and should indeed change the modes of understanding, formulation and presentation of the evangelical message, but not the message itself. The aim is to incarnate Christianity in African religious worldview, so that "a better view will be gained on how African customs, outlook on life, and social order can be reconciled with the manner of living taught by divine revelation.

Inculturation on the other hand, is the process through which the gospel message is incarnated in a particular human culture. Inculturation is therefore, as it were a corollary of evangelization. For if the gospel must encounter all nations and Christianize them, it must also encounter and transform their cultures (Ikenga-Metuh, 1996). Jesus the Word of God made man, was born into the Jewish culture and his life and message found expression in Judeo-Greek culture of his time. And as the gospel was carried from one culture to the other, it was found necessary to decode the divine message from the cultural idiom of the evangelizers, and re-encode it in the cultural idiom of the evangelized in order to make the message meaningful to them and eventually remain incarnated in their own culture.

Christian theology must, therefore be informed by the contextual milieu of its target audience in such a way that the 
word will become flesh among the people (Ajah, 1996). Early missionaries studied the culture of India, China, Japan, Latin America and Australia. But in regards to Africa, especially the sub-Saharan Africa, they did not feel or think that it was necessary to study the people and their ways at all.

\section{Casual Factors to the Emergence of Incarnational Theology in Africa}

The casual factors to the indent of incarnational theology include missionary factor and theological unreality of the missionaries. Other factors that gave rise to incarnational theology in Africa include cultural and intellectual developments and religious developments. In the former, the Europeans invaded Africa on the basis of wealth and power. The Berlin Conference of 1884-85 was concerned to stop the wars and the scrambling by amicable partitioning of Africa among them. Above all, colonial educational system did not allow the African to reflect on personal identity. Again, political independence in Africa has not included ideological independence. Doing incarnational theology in Africa therefore, is a quest for selfhood or self-consciousness and must be put in that context to ensure proper understanding and representation. The writings which interact with pre-colonial, colonial, and post-colonial Africa, presuppose that African identity was lost to foreign influence in the nineteenth century.

The implication here is that the political and religious intrusion of the white man in the $19^{\text {th }}$ century Africa has robbed Africans of their cultural identity. The incarnational theological method, on the other hand, includes that this divine self-disclosure in Jesus Christ is a continuous process which becomes existentially salvafic only when each people perceive and appropriate it in their cultural context. In this respect therefore, the term "incarnational theology in Africa", simply means, a Christian theology presented in the framework of African history and culture, especially as it affects existential issues in the self-consciousness of the African.

Generally, two things are involved in the missionary factor in this context. The first deals with the missionaries as partners with colonial imperialism in Africa. The second accuses missionaries of what Professor Kwesi Dickson classified as, "Theological unreality in the in Africa" (Dickson, 1984 p. 89). Christianity is therefore still a stranger in the real life situation of Africans. All cultural practices which could not be understood by the missionaries were stamped out. The criterion for judging African traditional life therefore, was western worldview. They were so strict that Christian converts were completely separated from African life and thought, since everything was considered "pagan." The concept of "conversation" in the western missionaries' theology was a blanket concept which presupposed condemnation of everything with which the peoples of Africa were associated. That includes their cultural values which gave them their self-worth.

\section{Origin of African Incarnational Theology}

The growth of African Incarnational Theology could be seen against the background of attempts made during the missionary era at the "adaptation" of the gospel message to facilitate the implantation of the church in mission lands. In effect, this effort went no further than mere translation, that is, using the local languages and elements in the local cultures to facilitate the "transplant" of a European model of a particular denomination to Africa.

The term "adaptation" and the approach it designates, has been abandoned as too superficial and inadequate. Similarly, terms such as "indigenization", "Africanization" "accommodation", and Christianization" have also been abandoned for not going far enough. Many African theologians today would rather opt for the term "inculturation" and call for African inculturation theology. Some prefer the term "incarnation" (Ikenga-Metuh, 1996). Adaptation is abandoned as being also top superficial and inadequate. It is similar to Africanization, accommodation, and Christianization.

The term inculturation is a new term whose meaning has not been standardized by frequent and repeated use. The term is borrowed from cultural anthropology where it usually has the form of "inculturation" (Crollius, 1986). Given that inculturation in cultural anthropology denotes the process by which an individual becomes inserted in his cultures. But in missiological studies, the term inculturation is now used to denote the process by which the church becomes inserted in a given culture. It must be distinguished from acculturation, the term also used in cultural anthropology to denote "culture contact", or the interaction which result when two or more cultures come into contact.

Inculturation is archived when the gospel message has so penetrated a given culture that it becomes as it were the life principle of that culture and now expresses itself through it. Inculturation takes place therefore, when a group of the Christian faithful in a particular locality, which has received the gospel, succeeds in divesting it of the non-essential cultural packaging with which it was brought, and re-expresses and lives it in the cultural idioms of the locality without compromising the essence of the message. It thus becomes an inculturated church, a fully developed local church "already rooted in the social life and considerably adapted to the local culture. 


\section{The Bi-Polar Nature of Theology}

For theology to be bi-polar in nature simply means that theology is a pole of two ends. It has the "eternal truth" on the one end and human situation on the other. The elements for theologizing are therefore, divine and human-the eternal and the temporal. There is nothing to theologize if you omit either of the two ends. Put more precisely in this scheme, "Theology moves back and forth between two poles, the eternal truth of its foundation (that is divine revelation) and the temporal situation (that is human culture) in which the eternal truth must be received

The divine revelation is to meet the existential needs of man. The term "existential needs of man" in this context means the actual realities as presented in common human experience; the practical issues and questions confronting man in his time and space. It includes man's self-consciousness as it is related to his contemporary world. But more strictly, divine revelation as "pole one" source of theology, refers to what is called eternal truth-the Christian message namely, that God was in Christ reconciling the world to himself. Secondly, divine revelation is universal.

Theology is also only perceived through cultural context (human culture). No human perception is pure; "every perception is tainted by the distorting effect of one's culture", that is, that each human, shaped by his culture, perceives things only as they appear to him in his context. In that context, "The doctrine of incarnation itself was the early church's affirmation of the reality of divine interaction with man in history. In other words, the incarnation of God in Jesus Christ is God's bi-polar archetypal model whose revelatory motif the theologian should borrow. According to Imasogie's approach for doing incarnational theology in Africa cited in Onyenechehie (2007), theology must be bi-polar in nature before it can be truly incarnational into any given worldview. For theology to be bi-polar in nature simply means that theology is a pole of two ends. It has the "eternal truth" (divine revelation) on the one end and human situation (human nature) on the other. The elements for theologizing are therefore, divine and human-the eternal and the temporal. There is nothing to theologize if you omit either of the two ends.

The first reason for using bi-polar theology is that it presupposes that the task of theology is to meet the existential needs of man in his generation. The term "existential needs of man" in this context means the actual realities as presented in common human experience; the practical issues and questions confronting man in his time and space. It includes man's self-consciousness as it is related to his contemporary world. Secondly, the background to this presupposition that theology should meet the existential need of the contemporary man is found in the challenge of the enlighten.

What Imasogie over looks in this discussion is the fact that the concept of relativity draws a line of distinctiveness which does not see universal objectivity in any human scheme which may be used to assess any contributions which Africa, the west or other peoples may want to make for the Christian theology. Theological relativity therefore, means that epistemological questions are only valid when answered in context.

\section{Method of Incarnational Theology in Africa}

The incarnational theological method, on the other hand, includes that this divine self-disclosure in Jesus Christ is a continuous process which becomes existentially salvafic only when each people perceive and appropriate it in their cultural context. In this respect therefore the term "Incarnational Theology in Africa" simply means a Christian theology presented in the framework of African history and culture especially as it affects existential issues in the selfconsciousness of the African (Onyenechehie, 2007).

Christ is clearly given to us in scriptures. First, in the incarnation of Jesus Christ, God definitively revealed himself to us (Jn 1:18; Heb. 1:1-3; Col. 2:9). Secondly, the incarnation of God in Jesus Christ was for the purpose of man's redemption (Matt: 1:21; Lk.19:10, Jn 14:6; Acts 4:12). Thirdly, with the incarnation of Jesus Christ, God inaugurated his kingdom in part (Matt.12:28). Fourthly, he came in order to destroy the works of the devil (1Jn 3:8). At the cross he defeated the evil one. Fifthly, he came to establish the church as the locus of his kingdom and his change agent in the world. He was never caught captive by human cultural milieu. Jesus accommodated himself to human situations, but his inspiration came from the worldview of God's kingdom.

Where culture conflicted with the worldview of the kingdom, our Lord stood his ground even when his life was at stake. The motif of the incarnation included encounter. Whereas the bi-polar method of theology sees an incarnational motif which places revelation and culture on the table to sort out the differences and similarities and to bargain for what meets the existential need of man in his context, the notion of encounter shows that man in his culture is depraved and therefore cannot even see clearly what he needs spiritually and existentially.

Whereas some encounters still speak of "Christianizing African traditions," others speak of Africanizing Christianity". These two phrases unconsciously reflect different images of the Christian church. The former sees the 
church as culturally unified; the latter sees the church as a plurality in unity, a fellowship of local churches, exchanging among themselves their vision of the risen Christ in a bond of faith, hope, and love. We are back again at the concept of incarnation, for Christianity must become incarnate in African cultures. Christ is present in every human situation, in every community and every human tradition, and this fact must be rendered explicit. Africans must experience Christ in their own communities and within their own cultural traditions; they are not asked to react to someone else's experience of Christ.

\section{Problems Associated in Doing Incarnational Theology in Africa}

The fact that those who claim to have embraced the Christian faith can revert to African traditional religious practices in times of existential crisis is a witness that cannot be controverted by any theologian who knows Africa well enough. We do understand that culture is a living tradition. The vocation of Christianity is the reconciliation, or the unification of humankind. This definitely does not mean the imposition of a world culture. Christian reconciliation envisages a situation in which people of different cultures can exchange their different experiences and traditions even their different understandings of the same Jesus Christ, the Jesus Christ of the gospels and of Church tradition (Shorter, 1978). A universal or Catholic Church is one to which many cultures contribute. It is not the imposition of a worldwide Christian culture which is a shallow disguise for western culture. Respect for humanity means "nearness" or "localness." Christian message have to become flesh in human culture. The analogy, according to Onyenechehie (2007), has two levels: the literal and existential levels.

1. In respect of the literal level, citing Imasogie affirms that the historical incarnation of God in Jesus Christ denotes that God had to become man because he knows how difficult it is for humans to think and perceive things in the abstract.

2. Secondly, on existential level, Imasogie sees God in Jesus Christ as contextualizing himself in order to meet with man on the existential level of his need. This is the key contention which Imasogie draws from the Revisionist and the Liberation theologians. The method also limits the paradigmatic relevance of "Jesus of Nazareth" to the existential level of man's life in the temporal here and now. In this regard, the revelatory relevance of the incarnation of Jesus is accepted only on the basis of its temporal benefits.

There is no doubt that Jesus Christ met the existential needs of those to whom he was first incarnated. His miracles and associations with them prove that: He fed the people when they needed food (Jn: 6); he shared in the people's emotional feelings, even to the point of weeping and acting for them at the times of their sorrows (Jn11: 35ff)

The NT reports to a large extent how Jesus was concerned for the people's existential need was not all the reason for which he was incarnated. He did not feed them all the time at their demand (Jn 6:26-27); heal them all the time (2Cor.12:7-10), or perform signs all the time, especially when the people tended to demand or major on such ministries as the end in themselves (Matt. 12:38-45). The purpose of his miracles includes that of establishing his identity as God in the process of reclaiming his fallen creation (cf. Lk.4:18-19: The spirit of the Lord is upon me, because he anointed me to preach the gospel to the poor).

The motif of his incarnation was to reclaim creation, restoring man's broken relationships-spiritually, culturally, politically, economically, socially, and environmentally. The motif of God's incarnation in Jesus Christ is clearly given to us in scriptures. Incarnational theology in Africa cannot be understood apart from its socio-cultural and intellectual context. The complex developments that have taken place in Africa during the $19^{\text {th }}$ and $20^{\text {th }}$ centuries are key for a proper understanding of the rise and impetus of incarnational theology. This could be seen from the colonial and post-colonial factors.

Effective incarnational theology in Africa must be Christ-centric. That is, if theology must be incarnational, then the incarnate Christ must be at its center. Christo-centric theology literally means Christ centered theology. Furthermore, Africans need to be shown once more that the offices which Jesus occupies in scripture as the prophet (Deut.18:15; Acts 3:22-25, 7:37; Matt.5:21-22, 27-28,31-34, 7:24ff; Jn 1:18; Col.2:9; Heb.1:3); the priest (1Tim.2:5; Heb.7:15-17,9:24-28, 10:9-12; 1Jn 1:2; 2Cor.5:21; Jn 17:91:9; Rom.5:6-8; 1Jn 2:2; Heb.4:14-16, 7:25), and the king (Matt.4:17; 12:28,13; Acts 1:3; 2Cor.4:4; 1Pet 5:8).

\section{Conclusion and Recommendations}

It is also obvious that Christianity in the post-colonial Africa is still a foreigner or alien. It is equally certain that the average Africa Christians are not truly committed to their faith in Christ. The contention of this research therefore is that the time has arrived for the incarnate Christ to be brought back to the center of all Christian theological discussion in Africa. There 
is certainly no doubt that African theologians deserve commendation for making reasonable attempts so far in their search for theological relevance in Africa. Certainly, Christian theology cannot be incarnational in context unless it is Christo-centric in nature. It is hoped that theological discussions which are now going on in Africa will go beyond mere identification of the theological ills done on Africa since the $19^{\text {th }}$ century. A sense of direction must be sought by African theologians from the head of the church, Jesus Christ himself.

Evangelization for the Church is a command, "Go out to the whole world, proclaim the good news to all nations" (Mk. 16:15). The good news is best proclaimed when it is a case of primary or pastoral evangelization. Incarnating Christianity in African world-views therefore, is based on a solid theology of continuity between the general revelation as it is grasped and expressed in African cultures and the special revelation made by God in the Bible which reached its climax in Christ, the visible image of the invisible God.

In this study, we have confronted the structure of African world-views with the essentials of the gospel message. There are aspects of African world-views which are incompatible with Christian message. While there are others which are not only compatible with the gospel, but also which when incarnated with the light of gospel message would make the message more meaningful and more effective in the lives of the African peoples. For inculturation or incarnation is no other than the evangelization of culture. Incarnation (inculturation) is rooted in the incarnation of the Word of God (Logos). Because it was integral and concrete, the incarnation of the son of God was an incarnation into a culture.

Put simply, the process of incarnation of theology is the reverse of the process of adaptation. The process of adaptation entails the discovery of the good elements in non-Christian religions and introducing them into Christianity in one of its present historical cultural expressions.

\section{References}

Crollius, A.R. (1986). Inculturation: Newness and ongoing process. In Waliggo, J.M. etal (Eds.). Inculturation: its meaning and urgency. Nairobi: St. Paul.

Dickson, K. A. (1984). Theology in Africa. New York: Orbis Books.

Fashola-Luke, E. W. (1974). What is African Christianity theology? Viatoram: Communion.

Ikenga-Metuh, B. (Ed.). (1996). African inculturation theology: Africanizing Christianity. Onitsha: Imico Books.

Imasogie, O. (1983). Guiderlines for Christian theology in Africa. Accra: African Christian Press.

Onyenechehie, T. O. (2007). Doing incarnational theology in Africa: A Christo-centric approach. Aba: Assemblies of God Press.

Shorter, A. (1978). African Christian spirituality. London: Geoffrey Chapman.

Van, R. (Ed.). (nd). The Atlas of Africa. Paris: Jeune Afrique. 